\title{
Nodulation, yield and quality of soybean as influenced by integrated nutrient management
}

\author{
M. A. Alam ${ }^{1}$, A. Siddiqua ${ }^{2}$, M. A. H. Chowdhury ${ }^{1}$ and M. Y. Prodhan ${ }^{2}$ \\ ${ }^{1}$ Department of Agricultural Chemistry and ${ }^{2}$ Department of Biochemistry, Bangladesh Agricultural University, \\ Mymensingh-2202, Bangladesh
}

\begin{abstract}
A field experiment was conducted at the Horticultural Farm of Bangladesh Agricultural University, Mymensingh during the period from November 2007 to March 2008 to study the effect of integrated nutrient management on nodulation and sustainable soybean production. There were significant differences among the different treatment combinations in terms of yield and yield contributing characters. Integrated nutrient management with application of $50 \%$ of the recommended doses of urea, TSP, MOP, gypsum and biofertilizer (Bradyrhizobium) at the rate of $1 \mathrm{~kg} \mathrm{ha}^{-1}$ significantly increased most of the parameters, such as the highest plant height, number of nodule per plant, nodule dry weight per plant, pods per plant, grains per pod, grain yield, oil and protein contents. Coinoculation of Bradyrhizobium seemed to help reduce the NPKS requirement in soybean cultivation. Overall results indicate that the application of integrated nutrient management of biofertilizer (Bradyrhizobium) with $1 / 2$ NPKS of the recommended dose would produce the best quality of soybean with higher nodulation and yield.
\end{abstract}

Keywords: Nodulation, Integrated nutrient management, Inoculation

\section{Introduction}

Soybean (Glycine max L. Merril) is a very important recognized oil seed and protein crop in the world. It is a good source of protein, unsaturated fatty acids, minerals like $\mathrm{Ca}$ and $\mathrm{P}$ including vitamins $\mathrm{A}, \mathrm{B}$ and $\mathrm{D}$ that meet different nutritional needs (Rahman, 1982). The |seed contains about $40-45 \%$ protein, $18-20 \%$ edible oil and 20-26\% carbohydrate (Gowda and Kaul, 1982). The multipurpose use of soybean is gradually increasing day by day in our country.

Although soybean cultivation in Bangladesh is quite limited, there is an ample scope of increasing its cultivation through use of integrated nutrient management. In Bangladesh, about five thousand hectares of land is under soybean cultivation and annual production is approximately 4 thousand metric tons with an average yield of 1.5-2.3 $\mathrm{t} \mathrm{ha}^{-1}$ (BARI, 2006). Like other legume crops, it has the capacity to fix atmospheric nitrogen through root nodule bacteria. Bradyrhizobium can fix atmospheric nitrogen (about $300 \mathrm{~kg}^{-1} \mathrm{ha}^{-1} \mathrm{yr}^{-1}$ ) in symbiosis with soybean (Keyser, 1992). Thus it helps to increase the soil fertility and economic crop production not only for itself but also for the next cereal or non-legume crops grown in rotation thereby reducing the requirement of external use of nitrogen fertilization. Therefore, the present piece of research work was undertaken to study the effect of integrated nutrient management on the growth, yield and yield contributing characters of soybean.

\section{Materials and Methods}

The experiment was conducted at the Horticultural Farm of Bangladesh Agricultural University Mymensingh. The initial soil sample was collected from 0-15 cm depth from 10 different locations in the field with the help of auger. The composite soil sample was air dried, ground to pass through a 10 mesh $(2 \mathrm{~mm})$ sieve and stored in polythene bag for mechanical and chemical analyses. The experimental plot was properly prepared through several ploughing and cross ploughing to obtain good tilth. All weeds and stubbles were removed from the field and bigger clods were broken by laddering and mallet.

\section{Treatments and replication of the experiment}

The experiment was laid out in a Randomized Complete Block Design (RCBD) with three replications. The variety of the crop was Shohag recommended by the National Seed Board (NSB) of Bangladesh for cultivation. The experimental area was divided into eight unit plots with raised bands as per treatments. Thus the total number of unit plots was 24 . Treatments were randomly distributed within the blocks as follows: $T_{1}=$ Control (No fertilizer), $T_{2}=$ Chemical fertilizers ha ${ }^{-1}, 55 \mathrm{~kg}$ urea $+160 \mathrm{~kg}$ TSP $+110 \mathrm{~kg} \mathrm{MOP}+$ $50 \mathrm{~kg}$ Gypsum, $\mathrm{T}_{3}=15 \mathrm{t} \mathrm{ha}^{-1}$ Farm yard manure (FYM), $\mathrm{T}_{4}=1 \mathrm{~kg}$ ha-1Biofertilizer (BF), $\mathrm{T}_{5}=10 \mathrm{t}$ ha ${ }^{-1}$ Poultry manure (PM), $T_{6}=50 \%$ of the recommended dose of chemical fertilizers (NPKS) $+15 \mathrm{t} \mathrm{ha}^{-1}$ $\mathrm{FYM}, \mathrm{T}_{7}=50 \%$ of the recommended dose of chemical fertilizers (NPKS) $+1 \mathrm{~kg} \mathrm{ha}^{-1}$ Biofertilizer, $\mathrm{T}_{8}=50 \%$ of the recommended dose of chemical fertilizers (NPKS) $+10 \mathrm{t} \mathrm{ha}^{-1} \mathrm{PM}$. 


\section{Inoculation and sowing of seeds}

At first inoculated seeds were sown according to the experimental design for treatments $T_{4}$ and $T_{7}$. Prior to this, seeds were taken in small polythene bags equal in weight for each pot and mixed with sugarcane molasses (@30g molasses kg-1 seeds). Then the inoculum (Bradyrhizobium sp.) was mixed with the seeds @ $30 \mathrm{~g}$ inoculum $\mathrm{kg}^{-1}$ seeds for the treatments $\mathrm{T}_{4}$, and $\mathrm{T}_{7}$. For each inoculation, separate plastic bag was used and care was taken to avoid contamination of the inoculated and uninoculated seeds. Seeds were sown at 3-4 cm depth of soil. Row to row distance was $30 \mathrm{~cm}$ and seed to seed distance within a furrow was $5 \mathrm{~cm}$. Irrigation and weeding was done as and when necessary during the period of experimentation.

\section{Collection of different data}

Plant height: The heights of randomly selected three plants from each plot were recorded in centimeter from the base of the plant to the tip of the tallest leaf and expressed as mean values. The plant heights were measured at an interval of 30 days after sowing (DAS), e.g., 30, 60, 90 and 120 DAS.

Nodule number and nodule dry weight per plant: Three plants were randomly selected from each plot and were carefully uprooted to study the nodule number and nodule dry weight. Soil from the root was removed carefully and the nodules were separated and counted and sun dried for two days. Sun dried samples were then put in a paper packet and oven dried for 72 hours at $65-70^{\circ} \mathrm{C}$. After oven drying, nodules were weighed in an electric balance. The nodule number and nodule dry weight plant ${ }^{-1}$ were measured at 30 DAS, 60 DAS, 90 DAS and 120 DAS.

Harvesting and recording of plant data: Three plants from each plot were harvested, threshed, cleaned and processed for analysis. All pods were collected, counted and then averaged to find out pods plant ${ }^{-1}$. Randomly 10 pods were collected from each plant and number of seeds were counted and then averaged to find out the seeds pod $^{-1}$. Seeds of each plant were weighed and seed yield was recorded in gram and expressed in seed yield plant ${ }^{-1}$. By subtracting the seed weight from the weight of whole plants including seeds, the stover weight was obtained.

Seed oil content: The oil content of soybean seed was extracted by Folsch method (Folsch et al., 1957) by using chloroform: methanol in 2:1 ratio in a beaker with stirring. The extractant was removed by heating and oil obtained was expressed in percentage.

Protein content: Protein content was computed by multiplying $\mathrm{N}$ content in soybean seed determined by microkjeldahl assay by a conventional factor of 6.25 (Jackson, 1973).

Chlorophyll content in leaves: Total chlorophyll content was measured following the method of Arnon (1949). Fresh leaf samples $(0.05 \mathrm{~g})$, collected at mid flowering stage, were macerated in mortar and pestle with $80 \%$ acetone. It was then collected in a test tube and centrifuged at $3000 \mathrm{rpm}$ for 10 minutes. The volume was made to $10 \mathrm{~mL}$ with $80 \%$ acetone and the absorbance was measured at $663 \mathrm{~nm}$ and $645 \mathrm{~nm}$ in a spectrophotometer.

\section{Results and Discussion}

\section{Plant height}

Plant height of soybean responded significantly to the integrated use of biofertilizer (Bradyrhizobium) and $50 \%$ of the recommended dose of chemical fertilizers NPKS (Table 1). The highest plant height was observed at 120 DAS in the treatment $T_{7}(77.13 \mathrm{~cm})$ followed by the treatment $T_{6}(65.60 \mathrm{~cm})$ and the lowest was recorded in the control treatment $(41.60 \mathrm{~cm})$. This study is similar to that of Singh and Rai (2005) who observed that integrated use of chemical fertilizers and biofertilizer increased plant height significantly in soybean. 
Table 1. Integrated nutrient management on plant height at different days after sowing (DAS) of soybean

\begin{tabular}{|c|c|c|c|c|}
\hline \multirow{2}{*}{ Treatments } & \multicolumn{4}{|c|}{ Plant height (cm) } \\
\cline { 2 - 5 } & 30 DAS & 60 DAS & 90 DAS & 120 DAS \\
\hline$T_{1}$ & 8.68 & 24.33 & 37.00 & 41.60 \\
\hline$T_{2}$ & 10.67 & 28.67 & 40.07 & 41.53 \\
\hline$T_{3}$ & 8.88 & 28.88 & 39.57 & 42.42 \\
\hline$T_{4}$ & 10.40 & 29.37 & 36.97 & 43.65 \\
\hline$T_{5}$ & 10.09 & 29.23 & 37.07 & 47.58 \\
\hline$T_{6}$ & 10.35 & 30.27 & 62.07 & 65.60 \\
\hline$T_{7}$ & 12.70 & 31.93 & 67.23 & 77.13 \\
\hline$T_{8}$ & 12.47 & 31.37 & 59.50 & 63.53 \\
\hline LSD & 2.09 & 2.04 & 4.91 & 5.86 \\
\hline CV (\%) & 11.35 & 3.98 & 5.91 & 6.33 \\
\hline
\end{tabular}

LSD= Least Significant Difference, $C V=$ Coefficient of Variation

$\mathrm{T}_{1}=$ Control (No fertilizer), $\mathrm{T}_{2}=$ Chemical fertilizers ha ${ }^{-1}, 55 \mathrm{~kg}$ urea $+160 \mathrm{~kg}$ TSP $+110 \mathrm{~kg} \mathrm{MOP}+50 \mathrm{~kg}$ Gypsum, $\mathrm{T}_{3}$ $=15 \mathrm{t} \mathrm{ha}^{-1}$ Farm yard manure (FYM), $\mathrm{T}_{4}=1 \mathrm{~kg}^{-1} \mathrm{~h}^{-1}$ Biofertilizer (BF), $\mathrm{T}_{5}=10 \mathrm{tha}{ }^{-1} \mathrm{Poultry}$ manure (PM), $\mathrm{T}_{6}=50 \%$ of the recommended dose of chemical fertilizers (NPKS) $+15 \mathrm{t} \mathrm{ha}^{-1} \mathrm{FYM}, \mathrm{T}_{7}=50 \%$ of the recommended dose of chemical fertilizers (NPKS) $+1 \mathrm{~kg} \mathrm{ha}^{-1}$ Biofertilizer, $\mathrm{T}_{8}=50 \%$ of the recommended dose of chemical fertilizers (NPKS) $+10 \mathrm{tha}^{-1} \mathrm{PM}$.

\section{Number of nodules per plant}

The inoculation of Bradyrhizobium and chemical fertilization had a significant effect on total number of nodules plant ${ }^{-1}$ at different days after sowing (Table 2). Overall results indicate that the highest number nodule was observed in the treatment $T_{7}(46.28)$ followed by the treatment $T_{4}$ (39.53) at 60 DAS. The results also showed that integrated use of biofertilizer (Bradyrhizobium) and $1 / 2$ chemical fertilizers (NPKS) substantially increased the nodule number compared with other treatments. So, biofertilizer (Bradyrhizobium) and 50\% of the recommended dose of chemical fertilizers (NPKS) seemed to have an effect on nodulation of soybean crop. The nodule number of plant was gradually decreased after 60 DAS to 120 DAS in all the treatments. The lowest number of nodule was recorded in 120 DAS overall in all the treatments presumably due to root senescence during ripening stage of the crop. The reason of the maximum nodulation in inoculated plants was probably due to the fact that Bradyrhizobium aids in nodulation. This result comply with that of Egamberdiyeva et al., (2004) who observed significantly higher number of nodules produced in inoculated plants compared with uninoculated one.

Table 2. Integrated nutrient management on nodule number per plant at different days after sowing (DAS) of soybean

\begin{tabular}{|c|c|c|c|c|}
\hline \multirow{2}{*}{ Treatments } & \multicolumn{4}{|c|}{ Number of nodule per plant } \\
\cline { 2 - 5 } & 30 DAS & 60 DAS & 90 DAS & 120 DAS \\
\hline $\mathrm{T}_{1}$ & 5.48 & 12.79 & 3.12 & 1.05 \\
\hline $\mathrm{T}_{2}$ & 11.07 & 25.10 & 4.56 & 2.86 \\
\hline $\mathrm{T}_{3}$ & 6.87 & 18.43 & 5.47 & 0.93 \\
\hline $\mathrm{T}_{4}$ & 18.87 & 39.53 & 12.70 & 3.90 \\
\hline $\mathrm{T}_{5}$ & 11.06 & 18.75 & 4.90 & 1.43 \\
\hline $\mathrm{T}_{6}$ & 12.08 & 24.83 & 4.10 & 2.04 \\
\hline $\mathrm{T}_{7}$ & 23.08 & 46.28 & 14.60 & 5.00 \\
\hline $\mathrm{T}_{8}$ & 12.87 & 34.82 & 4.57 & 2.25 \\
\hline $\mathrm{LSD}$ & 2.89 & 6.56 & 2.45 & 0.80 \\
\hline CV (\%) & 12.79 & 9.43 & 11.01 & 10.34 \\
\hline
\end{tabular}

LSD= Least Significant Difference, $C V=$ Coefficient of Variation 


\section{Dry weight of nodule per plant}

Integrated use of biofertilizer (Bradyrhizobium) and $50 \%$ of the recommended dose of chemical fertilizers (NPKS) significantly increased the dry weight of nodule at different DAS (Table 3). The highest nodule dry weight was observed in the treatment $T_{7}(97.19 \mathrm{mg})$ followed by the treatment $T_{4}(83.02 \mathrm{mg})$ at 60 DAS. The treatment $\left(T_{1}\right)$ produced lowest (26.86) dry weight. Hoque and Hashem (1994) observed that inoculation with Bradyrhizobium increased nodule dry weight of soybean.

Table 3. Integrated nutrient management on dry weight of nodule per plant at different days after sowing (DAS) of soybean

\begin{tabular}{|c|c|c|c|c|}
\hline \multirow{2}{*}{ Treatments } & \multicolumn{4}{|c|}{ Dry weight of nodule per plant (mg) } \\
\cline { 2 - 5 } & 30 DAS & 60 DAS & 90 DAS & 120 DAS \\
\hline $\mathrm{T}_{1}$ & 4.11 & 26.86 & 2.68 & 0.90 \\
\hline $\mathrm{T}_{2}$ & 8.29 & 52.71 & 3.93 & 2.46 \\
\hline $\mathrm{T}_{3}$ & 5.18 & 38.85 & 4.88 & 0.80 \\
\hline $\mathrm{T}_{4}$ & 14.08 & 83.02 & 10.92 & 4.21 \\
\hline $\mathrm{T}_{5}$ & 8.33 & 39.35 & 4.21 & 0.94 \\
\hline $\mathrm{T}_{6}$ & 9.06 & 52.15 & 3.53 & 1.73 \\
\hline $\mathrm{T}_{7}$ & 17.14 & 97.19 & 12.56 & 4.30 \\
\hline $\mathrm{T}_{8}$ & 9.65 & 73.11 & 3.93 & 1.92 \\
\hline LSD & 2.10 & 13.87 & 1.25 & 0.78 \\
\hline CV (\%) & 12.60 & 13.68 & 11.01 & 2.92 \\
\hline
\end{tabular}

LSD= Least Significant Difference, CV= Coefficient of Variation

\section{Yield and yield contributing characters}

Pods plant ${ }^{-1}$ and seeds pod $^{-1}$ was significantly influenced by the integrated use of biofertilizer (Bradyrhizobium) with $50 \%$ of the recommended dose of chemical fertilizers (Table 4). Maximum number of pods plant ${ }^{-1}$ (38.17) and seeds pod $^{-1}$ (3.18) were recorded in the treatment $T_{7}$ followed by the treatment $T_{8}$. The minimum was in the control treatment $T_{1}(15.23)$ for pods plant ${ }^{-1}$ and (1.97) for seeds pod ${ }^{-1}$. The result of pods plant ${ }^{-1}$ was similar to the finding of Tomar et al. (2004), who observed that soybean plants treated with Bradyrhizobium inoculants significantly increased the number of pods plant $^{-1}$ and the finding of seeds pod ${ }^{-1}$ was similar to the study of Jain and Trivedi (2005) who reported that the soybean plants treated with Bradyrhizobium alone or in combination with different levels of chemical fertilizers gave highest number of seeds pod $^{-1}$.

The100-grain weight was not significantly influenced by the integrated use of biofertilizer (Bradyrhizobium) with or without organic and inorganic fertilizers (Table 4). The 100-grain weight varied from $12.10 \mathrm{~g}$ to $13.50 \mathrm{~g}$ due to the different treatments. The maximum grain weight $(13.50 \mathrm{~g})$ was observed in Bradyrhizobium inoculant with 50\% of the recommended dose of chemical fertilizers (NPKS) followed by $\mathrm{T}_{4}(13.45 \mathrm{~g})$. The lowest grain weight $(12.10 \mathrm{~g})$ was recorded in the control treatment $\mathrm{T}_{1}$. The present results were in agreement with those of Podder et al. (1999) who reported that 100-grain weight increased by inoculants significantly over uninoculated control.

Grain yield was significantly influenced by the integrated use of biofertilizer (Bradyrhizobium) with or without organic and inorganic fertilizers (Table 4). The grain yield varied from 1.12 to $2.98 \mathrm{t} \mathrm{ha}^{-1}$ in the different treatments. The maximum grain yield $\left(2.98 \mathrm{t} \mathrm{ha}^{-1}\right)$ was observed by the application of biofertilizer (Bradyrhizobium) with $50 \%$ of the recommended dose of chemical fertilizers (NPKS) followed by treatment $\mathrm{T}_{6}\left(2.23 \mathrm{t} \mathrm{ha}^{-1}\right)$. The lowest grain yield $\left(1.12 \mathrm{t} \mathrm{ha}^{-1}\right)$ was recorded in the uninoculated treatment $\mathrm{T}_{1}$. Coinoculation of biofertilizer with $50 \%$ of the recommended dose of chemical fertilizers (NPKS) showed better performance.

Influence of integrated use of biofertilizer (Bradyrhizobium) and 50\% of the recommended dose of chemical fertilizers (NPKS) on stover yield of soybean was significant (Table-4). All the treatment gave significantly higher stover yield over the control. The stover yield ranged from 1.24 to $3.48 \mathrm{t} \mathrm{ha}^{-1}$ in different treatments. The highest stover yield was obtained in treatment $T_{6}\left(3.48 \mathrm{t} \mathrm{ha}^{-1}\right)$ followed by the treatment $\mathrm{T}_{7}\left(3.39 \mathrm{t} \mathrm{ha}^{-1}\right)$. The results of grain yield and stover yield was similar to the study of Jain and Trivedi (2005) who reported that the soybean plants treated with Bradyrhizobium alone or in combination with NPKS gave the highest grain yield and stover yield.

Alam et al. 
Table 4. Effect of integrated nutrient management on yield and yield contributing characters of soybean at harvest

\begin{tabular}{|c|c|c|c|c|c|}
\hline Treatments & $\begin{array}{c}\text { Pods plant }^{-1} \\
\text { (No.) }\end{array}$ & $\begin{array}{c}\text { Grains pod } \\
\text { (No.) }\end{array}$ & $\begin{array}{c}100 \text { grain } \\
\text { weight(g) }\end{array}$ & $\begin{array}{c}\text { Grain yield } \\
\left(\mathrm{t} \mathrm{ha}^{-1}\right)\end{array}$ & $\begin{array}{c}\text { Stover yield } \\
\left(\mathrm{t} \mathrm{ha}^{-1}\right)\end{array}$ \\
\hline $\mathrm{T}_{1}$ & 15.23 & 1.96 & 12.10 & 1.12 & 1.24 \\
\hline $\mathrm{T}_{2}$ & 26.60 & 2.30 & 13.17 & 2.16 & 2.98 \\
\hline $\mathrm{T}_{3}$ & 27.43 & 2.33 & 13.15 & 1.32 & 3.34 \\
\hline $\mathrm{T}_{4}$ & 30.53 & 2.30 & 13.45 & 1.14 & 1.83 \\
\hline $\mathrm{T}_{5}$ & 24.49 & 2.50 & 12.96 & 1.13 & 1.92 \\
\hline $\mathrm{T}_{6}$ & 32.85 & 2.50 & 12.15 & 2.23 & 3.48 \\
\hline $\mathrm{T}_{7}$ & 38.17 & 3.18 & 13.50 & 2.98 & 3.39 \\
\hline $\mathrm{T}_{8}$ & 33.06 & 2.66 & 12.65 & 1.99 & 3.30 \\
\hline LSD & 10.09 & 0.53 & 0.71 & 5.53 & 3.24 \\
\hline CV $(\%)$ & 10.13 & 12.33 & 3.13 & 9.30 & 8.28 \\
\hline
\end{tabular}

LSD= Least Significant Difference, $C V=$ Coefficient of Variation

\section{Chlorophyll content in leaf, oil and protein contents of soybean seeds}

Table 5 presents chlorophyll content of leaf and oil and protein content of soybean seeds. The chlorophyll content of soybean leaves and oil content of soybean seeds were not significantly influenced by the application of integrated use of biofertilizer (Bradyrhizobium) and 50\% of the recommended dose of chemical fertilizers (NPKS), but the protein content of soybean seed was significantly influenced by the different treatments. The highest chlorophyll content $\left(2.03 \mathrm{mg} \mathrm{g}^{-1}\right)$, oil content $(20.25 \%)$ and protein content $(38.75 \%)$ were obtained in the treatment $T_{7}$ and the lowest chlorophyll content $\left(1.68 \mathrm{mg} \mathrm{g}^{-1}\right)$, oil content $(14.20 \%)$ and protein content $(34.24 \%)$ were obtained in control treatment $\left(T_{1}\right)$. Similar results were also found by Singh and Rai (2005) in soybean.

Table 5. Effect of integrated nutrient management on chlorophyll, oil and protein content of soybean

\begin{tabular}{|c|c|c|c|}
\hline Treatments & Chlorophyll content $\left(\mathrm{mg} \mathrm{g}^{-1}\right)$ & Oil content (\%) & Protein content (\%) \\
\hline T1 & 1.68 & 14.20 & 34.24 \\
\hline T2 & 1.94 & 16.29 & 34.62 \\
\hline T3 & 1.74 & 15.20 & 34.90 \\
\hline T4 & 1.61 & 19.18 & 37.91 \\
\hline T5 & 1.70 & 17.26 & 35.62 \\
\hline T6 & 1.97 & 18.75 & 37.70 \\
\hline T7 & 2.03 & 20.25 & 38.75 \\
\hline T8 & 1.97 & 19.25 & 38.02 \\
\hline LSD & 0.48 & 4.49 & 5.03 \\
\hline CV (\%) & 15.57 & 14.17 & 9.30 \\
\hline
\end{tabular}

LSD= Least Significant Difference, $C V=$ Coefficient of Variation

The application of integrated nutrient management of biofertilizer (Bradyrhizobium) with $50 \%$ of the recommended dose of chemical fertilizers (NPKS) produced the best quality of soybean with higher nodulation and yield. Biofertilizer (Bradyrhizobium) alone or integrated with either organic or inorganic fertilizer can be used to obtain better yield of soybean and sustained soil fertility.

\section{References}

Arnon, D.I. 1949. Copper enzymes in isolated chloroplasts polyphenoloxidase in beta vulgaris. PI. Physic. $24:$ 4-5.

BARC (Bangladesh Agricultural Research Council). 2005. Fertilizer Recommendation Guide. New Airport Road, Farmgate, Dhaka. pp. 85-96.

BARI (Bangladesh Agriculture Research Institute). 2006. Krishi Projukti Hatboi (in Bangla). $4^{\text {th }}$ ed., Bangladesh Agril. Res. Inst., Gazipur, Bangladesh. p. 209-211. 
Egamberdiyeva, D., Qarshieva, D. and Davranov, K. 2004. The use of Bradyrhizobium to enhance growth and yield of soybean in calcareous soil in Uzbekistan. J. Plant Growth Regulation. 23(1): 54-57.

Folsch, J., Lees, M. and Stanley, G.H.S. 1957. A simple method for the isolation and purification of total lipids from animal's tissues, J. Bio.Chem. 226: 497-509.

Gowda, C.L.L. and Kaul, A.K. 1982. Pulses in Bangladesh. BARI and FAO Publication, Gazipur, Bangladesh. pp. 338-407.

Hoque, M.S. and Hashem, M.A. 1994. Field evolution of some promising Bradyrhizobium inoculants on soybean and groundnut at different locations. Bangladesh Agril. Univ., Res. Prog. 8: 118-122.

Jackson, M.L. 1973. Soil Chemical Analysis. Prentice Hall of India Pvt. Ltd. New Delhi, India: 10-44.

Jain, P.C. and Trivedi, S.K. 2005. Response of soybean (Glycine max (L.) Merrill) to phosphorus and bioferitlizers. Legume Res. 28(1): 30-33.

Keyser, H.H. and Li, F. 1992. Potential for increasing biological nitrogen fixation in soybean. Plant Soil. 141: 119-135.

Podder, A.K., Hossain, M.B., Chanda, M.C., Islam, M.Z. and Rahman, M. 1999. Selection of effective bradyrhizobial strains for soybean cultivation for environmental management of Brahmaputra Floodplain Soil. Bangladesh J. Environ. Sci. 5: 56-60.

Rahman, L. 1982. Cultivation of soybean and its uses. City Press, Dhaka: 5-7.

Singh, R. and Rai, R.K. 2005. Yield attributes, yield and quality of soybean as influenced by integrated nutrient management. India J. Agro.49 (4): 271-274.

Tomar, S., et at. 2004. Response of phosphorus, sulphur and rhizobium inoculation on growth, yield and quality of soybean (Glycine max L.). Prog. Agril. 7(1): 72-73. 